\title{
A Pan-European model of the Neolithic
}

\author{
Kate Davison', Pavel M. Dolukhanov², Graeme R. Sarson', \\ Anvar Shukurov' \& Ganna I. Zaitseva3 \\ 1 School of Mathematics and Statistics, University of Newcastle upon Tyne, NE1 $7 R U$, U.K. \\ kate.davison@ncl.ac.uk; g.r.sarson@ncl.ac.uk; anvar.shukurov@ncl.ac.uk \\ 2 School of Historical Studies, University of Newcastle upon Tyne, NE1 $7 R U$, U.K. \\ pavel.dolukhanov@ncl.ac.uk \\ 3 Institute for the History of Material Culture, Russian Academy of Sciences, St. Petersburg, Russia
}

\begin{abstract}
We present a mathematical model, based on a compilation of radiocarbon dates, of the transition to the Neolithic, from about 7000 to 4000 BC in Europe. With the arrival of the Neolithic, hunting and food gathering gave way to agriculture and stock breeding in many parts of Europe; pottery-making spread into even broader areas. We use a population dynamics model to suggest the presence of two waves of advance, one from the Near East, and another through Eastern Europe. Thus, we provide a quantitative framework in which a unified interpretation of the Western and Eastern Neolithic can be developed.
\end{abstract}

IZVLEČEK - Predstavljamo matematični model, ki temelji na kompilaciji radiokarbonskih datumov med 7000 in 4000 BC. Ti datumi so v Evropi povezani s prehodom v neolitik, ko sta poljedelstvo in živinoreja v mnogih regijah zamenjala lov in nabiralništvo; lončarstvo pa se je širilo še dlje. S pomočjo modela populacijske dinamike predstavljamo dva vala napredovanja, enega iz Bližnjega Vzhoda in drugega preko Vzhodne Evrope. Z njim zagotavljamo kvantitavni okvir, v katerem lahko razvijamo enovito interpretacijo 'zahodnega' in 'vzhodnega' neolitika.

KEY WORDS - Neolithic; population dynamics; radiocarbon dates; archaeology; mathematical modelling

\section{Introduction}

The transition to the Neolithic was a crucial period in the development of Eurasian societies, defining to a large extent their subsequent evolution. The introduction of agro-pastoral farming, which originated in the Near East about 12000 years ago and then spread throughout Europe, is usually considered to be a key feature of this transition (Zvelebil 1996). Yet the Neolithic was not a simple, single-faceted phenomenon. In his early definition of the Neolithic, Sir John Lubbock (1865) specified its main characteristics to be the growing of crops, the taming of animals, the use of polished stone and bone tools, and potterymaking.

Ceramic pottery is one of the defining characteristics of the Neolithic. It is true that there are examples of early farming communities apparently not involved in pottery-making. For example, aceramic Neolithic cultures have been identified in the Levant, Upper Mesopotamia, Anatolia (9800-7500 BC) and also in the Peloponnese (7000-6500 BC) and Thessaly Plain (7300-6300 BC). (All BC dates supplied are radiocarbon dates calibrated using OxCal v3.10 (Bronk Ramsey 2001) with calibration curve intcal04.14c.) Wheat, barley and legumes were cultivated at those sites; permanent houses with stone foundations were used. There is no widespread evidence of pottery (Perlès 2001) but recent excavations have revealed the occurrence of pottery in Thessaly, albeit in small quantities (J. K. Koztowski, personal communication 27/03/2007). In contrast, the Neolithic in NorthEastern boreal Europe is identified with a sedentary 
(or seasonally sedentary) settlement pattern, social hierarchy and sophisticated symbolic expression, the use of polished stone and bone tools, large-scale manufacture of ceramic ware, but not with agriculture (Oshibkina 1996): the subsistence apparently remained based on foraging. This combination of attributes is characteristic of the 'boreal Neolithic'; of these, pottery is in practice the most easily identifiable.

In the present paper we attempt to develop a unified framework describing the spread of both the 'agro-pastoral' and 'boreal' Neolithic. Our quantitative model of the Neolithization is based on the large amount of relevant radiocarbon dates now available.

\section{Selection of radiocarbon dates}

The compilation of dates used in this study to model the spread of the Neolithic in Europe is available upon request from the authors; unlike all other similar studies known to us it includes dates from the East of Europe. We used data from Gkiasta et al. (2003), Shennan and Steele (2000), Thissen et al (2006) for Southern, Central and Western Europe (SCWE) and Dolukhanov et al. (2005), Timofeev et al. (2004) for Eastern Europe (EE). Our selection and treatment of the dates, described in this section, is motivated by our attempt to understand the spread of agriculture and pottery making throughout Europe.

Many archaeological sites considered have long series of radiocarbon dates: often with 3-10 dates, and occasionally with 30-50. Associated with each radiocarbon measurement is a laboratory error, which after calibration was converted into a calibration error $\sigma_{\mathrm{i}}$. The laboratory error characterises the accuracy of the measurement of the sample radioactivity rather than the true age of the archaeological site (Dolukhanov et al. 2005) and, thus, is often unrepresentatively small, suggesting an accuracy of 30 years on occasion. Therefore, we estimated an empirical minimum error of radiocarbon age determination of the archaeological age and then used it when treating sites with multiple dates. A global minimum error of $\sigma_{\min }=160$ years is obtained from well explored, archaeologically homogeneous sites with a large number of tightly clustered dates. Such sites are: (1) Ilipinar, 65 dates, with the standard deviation $\sigma=168$ years (and mean date $6870 \mathrm{BC}$ ); (2) Achilleion, 41 dates, $\sigma=169$ years (mean $8682 \mathrm{BC}$ ); (3) Asikli Höyük, 47 dates, $\sigma=156$ years (mean $7206 \mathrm{BC}$ ). Similar estimates are $\sigma_{\min }=100$ years for LBK sites and $\sigma_{\min }=130$ years for the Serteya site in North-Western Russia (Dolukhanov et al. 2005); the typical errors vary between different regions and periods but we apply $\sigma_{\min }=160$ years to all the data here.

For sites with multiple radiocarbon date determinations, the dates are treated and reduced to two (and rarely more) dates that are representative of the arrival of multiple Neolithic episodes to that location. For the vast majority of such sites, the radiocarbon dates available can be combined, as discussed below, to just two possible arrival dates. Examples of sites with multiple radiocarbon measurements are Ilipinar and Ivanovskoye-2 where, respectively, 65 and 21 dates have been published. Figures $1 \mathrm{a}$ and $\mathrm{b}$ indicate that for these sites the series of dates form very different distributions; different strategies are used to process these different types of date series as described below (see Dolukhanov et al. 2005 for details). If a geographical location hosts only one radiocarbon measurement associated with the early Neolithic, then this is taken to be the most likely date for the arrival of the Neolithic. The uncertainty of this radiocarbon date is taken to be the maximum of the global minimum error discussed above and the calibrated date range obtained at the $99.7 \%$ confidence level and then divided by six (to obtain an analogue of the $1 \sigma$ error). There are numerous such sites in our collection, including Casabianca, Dachstein and Inchtuthil.

If only a few (less than 8) date measurements are available for a site and those dates all agree within the calibration error, we use their mean value and characterise its uncertainty with an error equal to the maximum of each of the calibrated measurement errors $\sigma_{i}$, the standard deviation of the dates involved $\sigma\left(t_{i}\right), 1 \leq i \leq n$, and the global minimum error introduced above:

$$
\sigma=\max \left\{\sigma_{i}, \sigma\left(t_{i}\right), \sigma_{\min }\right\}
$$

$n$ is the total number of dates in the cluster. An example of such a site is Bademağaci, where we have 4 dates, all within 60 years of one another; Figure 1c shows the histogram of radiocarbon dates of this site. The typical calibration error of these dates is approximately 30 years, thus Eq. (1) yields $\sigma_{\min }$ as an uncertainty estimate. However, we apply a slightly different procedure for clusters of dates that do not agree within the calibration error.

For a series of dates that cluster in time but do not agree within the calibration error, we use different approaches depending on the number of dates available and their errors. Should the cluster contain less 
than 8 dates, we take the mean of the dates (as in the previous case), as any more sophisticated statistical technique would be inappropriate for such a small sample; the error is taken as in Eq. (1). An example of such a site is Okranza Bolnica - Stara Zagora with 7 measurements, and Figure if shows that the dates are tightly clustered around the mean value.

If however, the date cluster is large (i.e. more than 8 dates, such as Ilipinar, shown in Fig. 1a), the $\chi^{2}$ statistical test can be used to calculate the most likely date $T$ of a coeval subsample as described in detail by Dolukhanov et al. (2005):

$$
T=\frac{\sum_{i=1}^{n} t_{i} / \bar{\sigma}_{i}^{2}}{\sum_{i=1}^{n} 1 / \bar{\sigma}_{i}^{2}},
$$

where $\bar{\sigma}_{i}=\max \left(\sigma_{i}, \sigma_{\min }\right)$. The coeval subsample is obtained by calculating the statistic:

$$
X^{2}=\sum_{i=1}^{n} \frac{\left(t_{i}-T\right)^{2}}{\bar{\sigma}_{i}^{2}}
$$

and comparing it with $\chi^{2}$. If $\mathrm{X}^{2} \leq \chi_{\mathrm{n}-1}^{2}$, the sample is coeval and the date $T$ is the best representative of the sample. If $X^{2}>\chi_{n-1}^{2}$, the sample is not necessarily coeval, and the dates that provide the largest contribution to $X$ are discarded one by one until the criterion for a coeval sample is satisfied. This process is very similar to that implemented in the $R_{-}$ Combine function of OxCal (Bronk Ramsey 2001). However, OxCal's procedure first combines the uncalibrated dates into one single radiocarbon measurement and then calibrates it. Our approach on the other hand first uses the calibration scheme of OxCal and then combines the resulting calibrated dates to give $T$. Furthermore, our procedure adds the flexibility of identifying and discarding dates with the largest relative deviation from $T$. Within $R_{-}$Combine the minimum error is not used in the calculation of $X^{2}$ but is rather only incorporated into the final uncertainty estimate. We feel that it is more appropriate to include the minimum uncertainty into the calculation from the outset. As a check, we combined several set of dates using both OxCal and our procedure, and the results agree within a few years in most cases where such agreement could be expected.

If a site has many radiocarbon determinations that do not cluster around a single date, a histogram of the dates is analyzed. If the data have a wide range and have no discernable peaks (i.e., are approximately uniformly distributed in time), they may suggest prolonged Neolithic activity at the site, and we choose, as many other authors, the oldest date (or one of the oldest, if there are reasons to reject outliers) to identify the first appearance of the Neolithic. Examples of such sites are Mersin and Halula where there are 6 and 9 dates with a range of 550 and 1900 years, respectively, and no significant peaks (see Figs. 1d and 1e), here the oldest dates are 6950 and 8800 years BC and the associated errors are 217 and 167 years.

Apart from sites with either no significant peak or only one peak, there are sites whose radiocarbon dates have a multimodal structure which may indicate multiple waves of settlement passing through this location. Ivanovskoye-2 (with 21 dates) is a typical site in this category, and Figure 1b depicts two distinct peaks. In such cases multiple dates were attributed to the site, with the above methods applied to each peak independently. Admittedly our method of assigning an individual date to a specific peak could be inaccurate in some cases as appropriate stratigraphic and/or typological data are not invoked in our procedure. In future refinements to this technique we may consider fitting bimodal normal distributions to the data to avoid the rigid assignment of measurements to one peak or another. After selection and processing, the total number of dates in our compilation is 477. In our final selection, 30 sites have two arrival dates allocated and 4 sites have three arrival dates allocated, namely Berezovaya, Osipovka, Rakushechnyi Yar and Yerpin Pudas.

\section{Modelling}

The mechanisms of the spread of the Neolithic in Europe remain controversial. Gordon Childe (1925) advocated direct migration of the farming population; this idea was developed in the form of the demic expansion (wave of advance) model (Ammerman and Cavalli-Sforza 1973). The Neolithization was viewed as the spread of colonist farmers who overwhelmed the indigenous hunter-gatherers or converted them to the cultivation of domesticated cereals and the rearing of animal stock (Price 2000). An alternative approach views the Neolithization as an adoption of agriculture (or other attributes) by indigenous hunter-gatherers through the diffusion of cultural novelties by means of intermarriages, assimilation and borrowing (Tilley 1994; Thomas 1996; Whittle 1996). Recent genetic evidence seems to favour cultural transmission (Haak et al. 2005).

Irrespective of the particular mechanism of the spread of the Neolithic (or of its various signatu- 
(a) Ilipinar

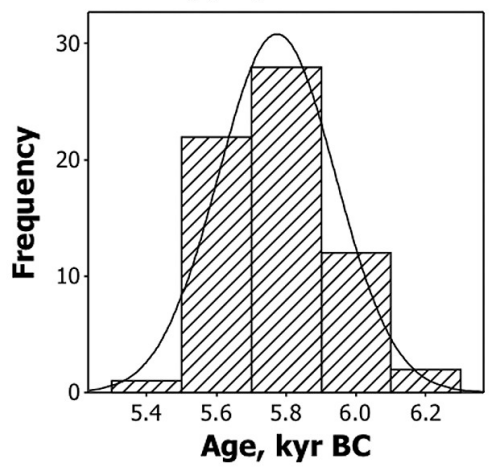

(d) Mersin

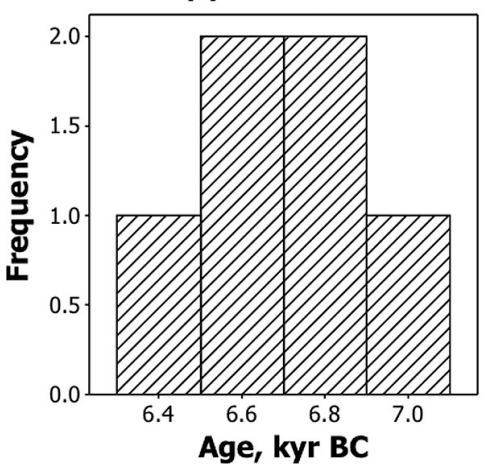

(b) Ivanovskoye-2

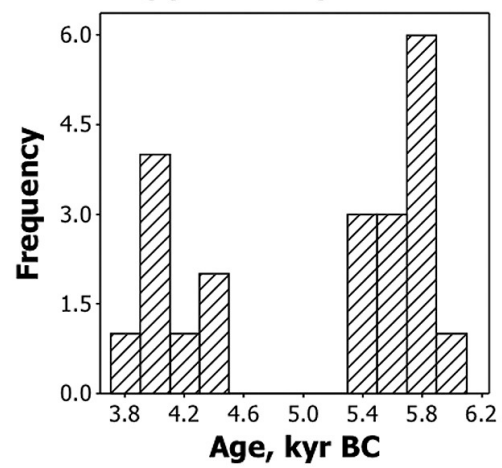

(e) Halula

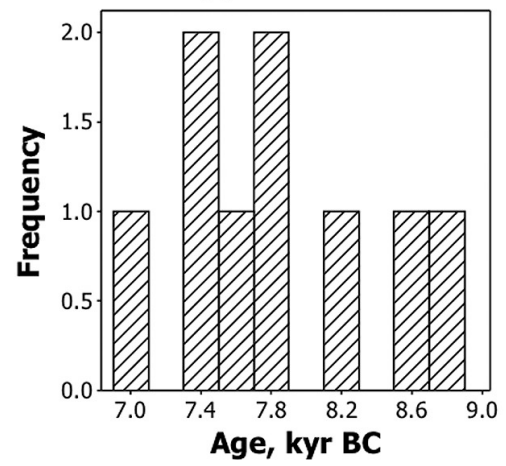

(c) Bademağaci

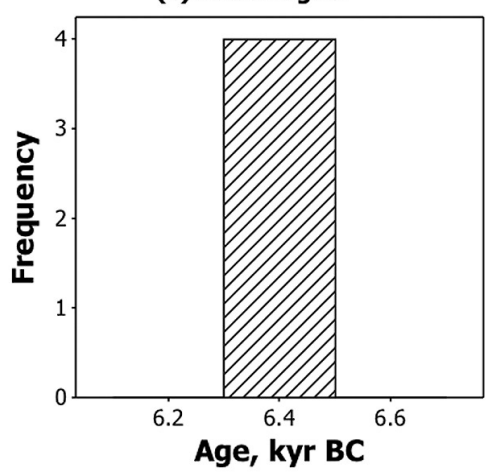

(f) Okrazna Bolnica-Stara Zagora

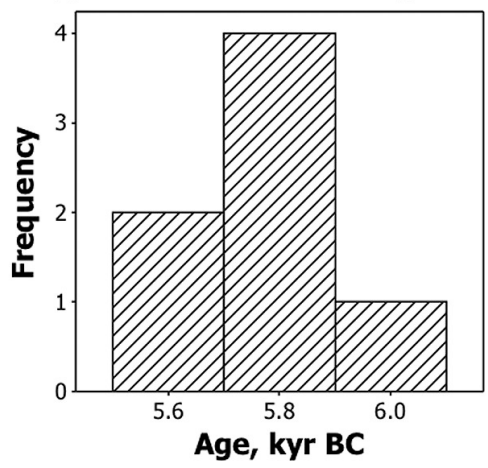

Fig. 1. Histograms of calibrated radiocarbon ages from archaeological sites in kyr BC, binned into 200 year intervals representing various temporal distributions. (a) The 65 dates from Ilipinar $\left(40.47^{\circ} \mathrm{N}\right.$, $29.30^{\circ} \mathrm{E}$ ) are approximately normally distributed, so the $\chi^{2}$ criterion can be employed to calculate the age of this site as described by Dolukhanov et al (2005). The resulting Gaussian envelope is shown solid. (b) Ivanovskoye-2 $\left(56.85^{\circ} \mathrm{N}, 39.03^{\circ} \mathrm{E}\right)$ has 21 dates showing a multimodal structure where each peak can be treated as above. (c) The 4 dates from Bademağaci $\left(37.40^{\circ} \mathrm{N}, 30.48 \mathrm{E}\right)$ combine into a single date when their errors are taken into account. (d) The 6 dates from Mersin $\left(36.78^{\circ} \mathrm{N}, 34.60^{\circ} \mathrm{E}\right)$ are almost uniformly distributed in time, so the oldest date can be used as representative of the arrival of the Neolithic. (e) The 9 dates from Halula $\left(36.40^{\circ} \mathrm{N}, 38.17^{\circ} \mathrm{E}\right)$ are treated as in (d). (f) The 7 dates from Okrazna Bolnica - Stara Zagora $\left(42.43^{\circ} \mathrm{N}, 25.63^{\circ} \mathrm{E}\right)$ are not numerous enough to justify the application of the $\chi^{2}$ test, but they form a tight cluster, so the mean date can be used for this site.

res), the underlying process can be considered as some sort of 'random walk', of either humans or ideas and technologies. Therefore, mathematical modelling of the spread (at suitably large scales in space and time) can arguably be based on a 'universal' equation (known as reaction-diffusion equation) with parameters chosen appropriately (Cavalli-Sforza and Feldman 1981). A salient feature of this equation is the development of a propagation front (where the population density, or any other relevant variable, is equal to a given constant value) which advances at a constant speed (Murray 1993) (in the approximation of a homogeneous, one-dimensional habitat). This mode of spread of incipient agriculture has been confirmed by radiocarbon dates (Ammerman and Biagi 2003; Ammerman and Cavalli-Sforza 1971; 1973; 1984; Gkiasta et al. 2003; Pinhasi et al. 2005). In Figure $2 \mathrm{a}$ we plot the distance from a putative source in the Near East versus the ${ }^{14} \mathrm{C}$ dates for early Neolithic sites in SCWE; the linear interdependence is consistent with a constant propagation speed. Due to the inhomogeneous nature of the landscape we would not expect to see a very tight correlation between distance from source and time of first arrival, since there are many geographical features that naturally cause barriers to travel (e.g. the Mediterranean Sea). It is also suggested in a previous work (Davison et al. 2006) that there are local variations in the propagation speed near major waterways; this again detracts from the constant rate of spread. In spite of this, the correlation coefficient is found to be -0.80 ; reassuringly high given the above complications. There is also a tail of older dates that originate in early Neolithic sites in the Near East, where a Neolithic tradition began and remained until it saturated the area and subsequently expanded across the landscape.

In contrast to earlier models, we include the 'boreal', East-European (EE) Neolithic sites, which we present 
in the same format in Figure $2 \mathrm{~b}$. It is clear that the Eastern data are not all consistent with the idea of spread from a single source in the Near East. A correlation coefficient of -0.52 between the $\mathrm{EE}$ dates and distance to the Near East is sufficient evidence for that. Our modeling, discussed below, indicates that another wave of advance swept westward through Eastern Europe about 1500 years earlier than the conventional Near-Eastern one; we speculate that it may even have spread further to produce early ceramic sites in Western Europe (e.g. the La Hoguette and Roucadour groups).

Our population dynamics model, described in detail by (Davison et al. 2006), was refined for our present simulations. We thus solve the reaction-diffusion equation supplemented with an advection of speed $\mathbf{V}$, arising from this anisotropic component of the random walk of individuals that underlies the large- scale diffusion (Davison et al. 2006; Murray 1993):

$$
\frac{\partial N}{\partial T}+(\mathbf{v} \cdot \nabla) N=\gamma N\left(1-\frac{N}{K}\right)+\nabla \cdot(v \nabla N)
$$

where $N$ is the population density, $\gamma$ is the intrinsic growth rate of the population, $K$ is the carrying capacity, and $v$ is the diffusivity (mobility) of the population. We solve Eq. (2) numerically in two dimensions on a spherical surface with grid spacing of $1 / 12$ degree (2-10 km, depending on latitude). All the variables in Eq. (2) can be functions of position and time, as described by Davison et al. (2006).

We consider two non-interacting populations, each modelled with Eq. (2), but with different values of the parameters $\mathbf{V}, \gamma, K$ and $v$; the difference is intended to represent differences between subsistence strategies (farmers versus hunter-gatherers) and/or between demic and cultural diffusion.

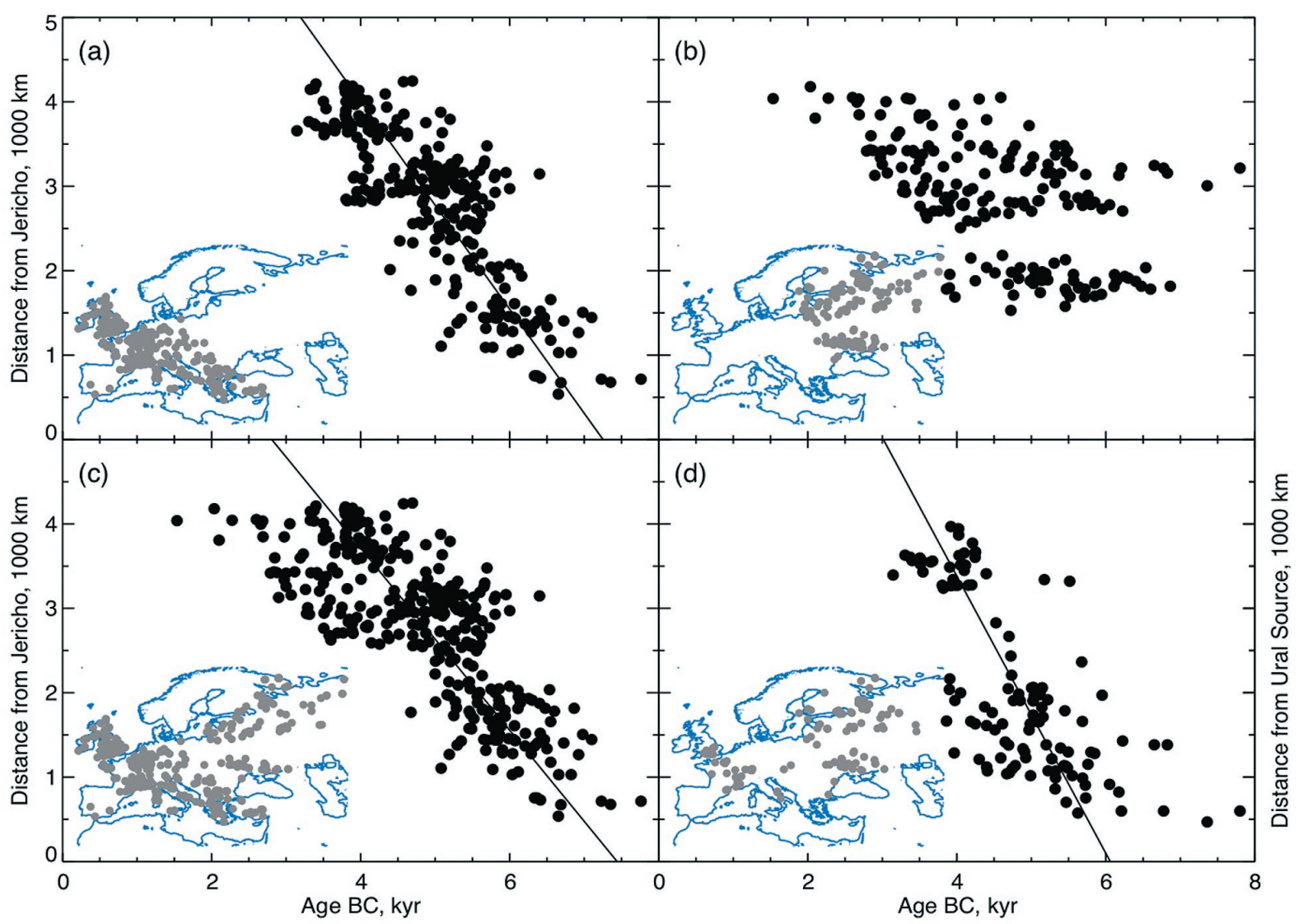

Fig. 2. Radiocarbon dates of early Neolithic sites versus the great-circle distance from the assumed source. Inset maps show the location of the sites plotted, and the straight lines correspond to spread at a constant speed given below. (a) Sites from Southern, Central and Western Europe (SCWE) with respect to a Near Eastern source (Jericho). The linear correlation (cross-correlation coefficient $\mathrm{C}=-0,80$ ) suggests a mean speed of advance of $U=1.2 \pm 0.1 \mathrm{~km} /$ year (2бerror). (b) Sites from Eastern Europe (EE) show very poor correlation with respect to the same Near-Eastern source $(\mathrm{C}=-0,52)$, so that straight-line fitting is not useful. (c) Sites attributed, using our two-source model, to the Near-Eastern source (note a significant number of EE sites clearly visible in the inset map) show a reasonable correlation $(C=-0,77)$ and a mean speed $\mathrm{U}=1.1 \pm 0.1 \mathrm{~km} /$ year. (d) Sites attributed to the Eastern source (from both EE and SCWE) show a correlation similar to that of Panel (c) $(\mathrm{C}=-0,76)$, and a mean speed $\mathrm{U}=1.7 \pm 0.3 \mathrm{~km} / \mathrm{year}$. 
We thus numerically solve two versions of Equation (2), one for each of two non-interacting populations with different origins of dispersal. The boundaries of the computational domain are at $75^{\circ} \mathrm{N}$ and $25^{\circ} \mathrm{N}$, and $60^{\circ} \mathrm{E}$ and $15^{\circ} \mathrm{W}$ as shown in Figure 3, they are chosen to comfortably incorporate our pan-European area. The environmental factors included into the model are the altitude, latitude, coastlines and the Danube-Rhine river system. The equation describing the farming population also includes advection velocity $\mathbf{V}$ along the major waterways (the Danube, the Rhine and the sea coastlines; $\mathbf{V} \neq 0$ within corridors $10 \mathrm{~km}$ wide on each side of a river or $10 \mathrm{~km}$ inshore near the sea) which results from anisotropic diffusion in those areas. The prescription of the components of the advective velocity are given in Davison et al. (2006).

The focus of our model is the speed of the front propagation $U$, since this quantity can be most readily linked to the radiocarbon age used to date the 'first arrival' of the wave of advance. This feature of the solution depends only on the linear terms in Equation (2) and, in particular, is independent of the carrying capacity $K$. Moreover, to a first approximation $U$ only depends on the product $w$ :

$$
U=2 \sqrt{\gamma} .
$$

Taking the intrinsic growth rate of a farming population as $\gamma=0.02$ year $^{-1}$ (Birdsell 1957), the mean speed of the front propagation of $U \approx 1 \mathrm{~km} /$ year for the population of farmers suggests the background (low-latitude) value of the diffusivity $v=12.5 \mathrm{~km}^{2} /$ year (Ammerman and Cavalli-Sforza 1971; Davison et al. 2006). For the wave spreading from Eastern Europe, $U \approx 1.6 \mathrm{~km} /$ year is acceptable as a rough estimate obtained from the EE radiocarbon dates (Dolukhanov et al. 2005); this estimate is confirmed by our model (see Fig. 2d). Analysis of the spread of Paleolithic hunter-gatherers yields $U \approx 0.8 \mathrm{~km} / \mathrm{year}$; the corresponding demographic parameters are suggested to be $\gamma=0.02-0.03$ year $^{-1}$ and $v=50-140$ $\mathrm{km}^{2} /$ year (Fort et al. 2004). These authors use an expression for $U$ different from Eq. (3); it is plausible, therefore, that the intrinsic growth rate obtained by Fort et al. (2004) for hunter-gatherers is a significant overestimate; for $v=100 \mathrm{~km}^{2} /$ year and $U \approx$ $1.6 \mathrm{~km} / \mathrm{year}$, the nominal value of $\gamma$ obtained from Eq. (3) is about 0.006 year $^{-1}$. A growth rate of $\gamma=$ 0.01 year $^{-1}$ has been suggested for indigenous NorthAmerican populations in historical times (Young and Bettinger 1992). The range $\gamma=0.003-0.03$ year $^{-1}$ is considered in a model of Paleoindian dispersal (Ste- ele et al. 1998). Our simulations adopt $\gamma=0.007$ year-1 and $v=91.4 \mathrm{~km}^{2} /$ year for the hunter-gatherers.

For the wave that spreads from the Near East carrying farming, $K$ and $v$ smoothly tend to zero within $100 \mathrm{~m}$ of the altitude $1 \mathrm{~km}$, above which land farming becomes impractical. For the wave spreading from the East, $K$ and $v$ are similarly truncated at altitudes around $1500 \mathrm{~km}$ as foraging is possible up to higher altitude than farming. The low-altitude (background) values of $K$ adopted are 0.07 persons $/ \mathrm{km}^{2}$ for hunter-gatherers (Dolukhanov, 1979; Steele et al. 1998) and 3.5 persons $/ \mathrm{km}^{2}$ for farmers, a value 50 times larger than that for hunter-gatherers $(\mathrm{Am}$ merman and Cavalli-Sforza 1984). The values of $K$ do not affect any results reported in this paper.

In seas, for both farmers and hunter-gatherers, both the intrinsic growth rate and the carrying capacity vanish as seas are incapable of supporting a human population. The diffusivity for both farmers and hunter gatherers tails off exponentially as

$$
v \propto \exp (-d / l)
$$

with $d$ the shortest distance from the coast and $l=$ $40 \mathrm{~km}$, allowing the population to travel within a short distance offshore but not to have a sustained existence there. The value of $l$ has been fine-tuned in this work in order to reproduce the delay, indicated by radiocarbon dates, in the spread of the Neolithic from the continent to Britain and Scandinavia. This provides an interesting inference regarding the sea-faring capabilities of the times, suggesting confident travel within about $40 \mathrm{~km}$ off the coast.

The inclusion of advection along the Danube-Rhine corridor and the sea coastlines is required to reproduce the spread of the Linear Pottery and Impressed Ware cultures obtained from the radiocarbon and archaeological evidence (see Davison et al. 2006 for details). The speed of spread of farming in the Danube-Rhine corridor was as high as $4 \mathrm{~km} / \mathrm{yr}(\mathrm{Am}$ merman and Cavalli-Sforza 1971) and that in the Mediterranean coastal areas was perhaps as high as $20 \mathrm{~km} / \mathrm{yr}$ (Zilhão 2001); we set our advective velocity in these regions accordingly. However, there are no indications that similar acceleration could occur for the hunter-gatherers spreading from the East. Thus, we adopt $\mathbf{V}=0$ for this population.

The starting positions and times for the two waves of advance - i.e., the initial conditions - were selected as follows. For the population of farmers, we position the origin and adjust the starting time so as 
to minimize the root mean square difference between the SCWE ${ }^{14} \mathrm{C}$ dates and the arrival time of the modelled population at the corresponding locations; the procedure is repeated for all positions between $30^{\circ} \mathrm{N}, 30^{\circ} \mathrm{E}$ and $40^{\circ} \mathrm{N}, 40^{\circ} \mathrm{E}$ with a $1^{\circ}$ step. This places the centre at $35^{\circ} \mathrm{N}, 39^{\circ} \mathrm{E}$, with the propagation starting at $6700 \mathrm{BC}$. For the source in the East of Europe, we have tentatively selected a region centered at $53^{\circ} \mathrm{N}, 56^{\circ} \mathrm{E}$ in the Ural mountains (to the east of the Neolithic sites used here), so that the propagation front reaches the sites in a well developed form. We do not suggest that pottery-making independently originated in this region. More reasonably, this technology spread, through the bottleneck between the Ural Mountains and the Caspian Sea, from a location further to the east. The starting time for this wave of advance was fixed by trial and error at $8200 \mathrm{BC}$ at the above location; this reasonably fits most of the dates in Eastern Europe attributable to this centre. For both populations, the initial distribution of $N$ is a truncated Gaussian of a radius $300 \mathrm{~km}$.

Comparison of the model with radiocarbon dates

The quality of the model was assessed by considering the time lag $\Delta T=T-T_{m}$ between the modelled arrival time(s) of the wave(s) of advance to a site, $T_{m}$, and the actual ${ }^{14} \mathrm{C}$ date(s) of this site, $T$, obtained as described in Sect. 2. The sites were attributed to that centre (Near East or Urals) which provided the smallest magnitude of $\Delta T$. This procedure admittedly favours the model, and the attributions have to be carefully compared with the archaeological and typological characteristics of each site. Such evidence is incomplete or insufficient in a great number of cases; we leave the laborious task of incorporating independent evidence in a systematic and de-

(a) $|\Delta T|<500$

(b) $500<|\Delta T|<1000$

(c) $|\Delta T|>1000$

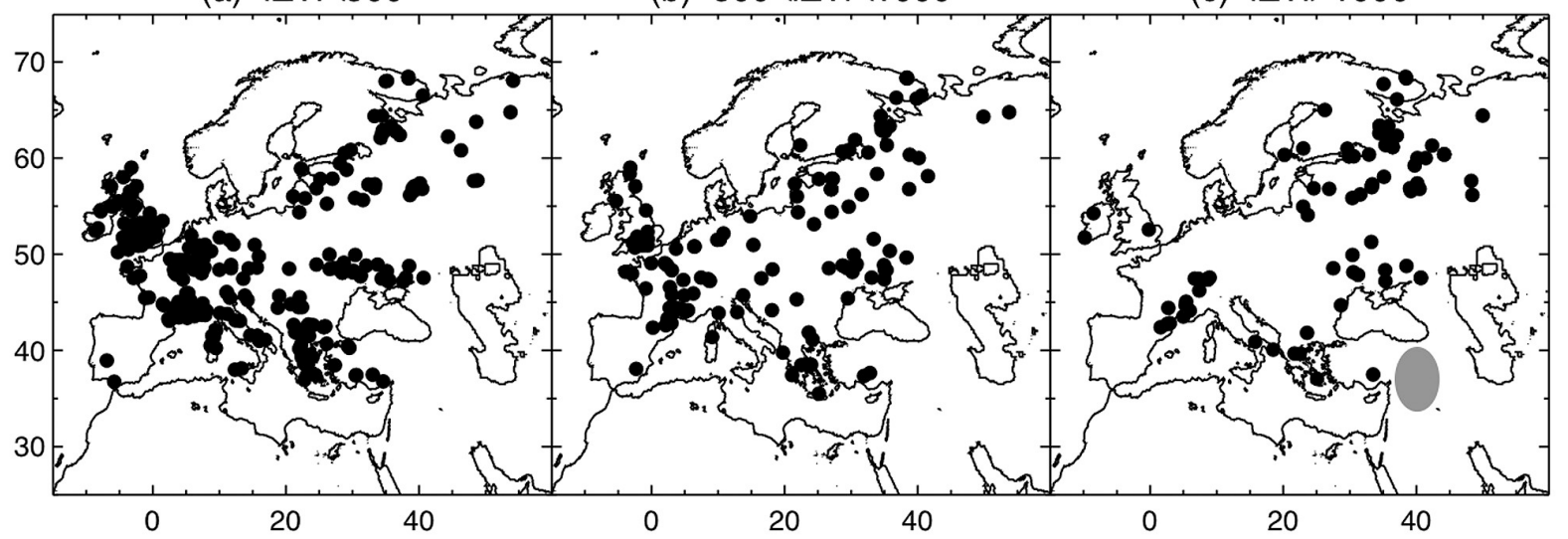

(d) $|\Delta T|<500$

(e) $500<|\Delta T|<1000$

(f) $|\Delta T|>1000$

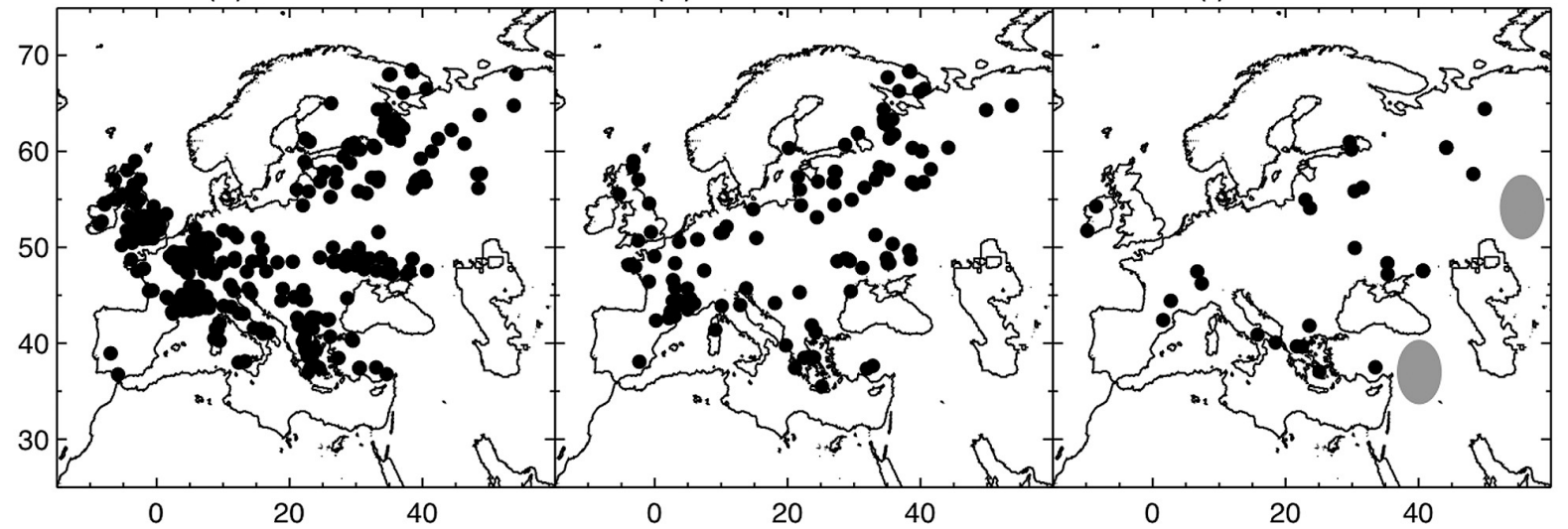

Fig. 3. Time lags, $\Delta \mathrm{T}=\mathrm{T}-\mathrm{T}_{\mathrm{m}}$, between the actual and modelled arrival times for the early Neolithic sites shown against their geographical position: panels (a)-(c) refer to a model with a single source in the Near East, and panels (d)-(f) to our best model with two sources (with the second on the Eastern edge of Europe). The positions of the sources are shown in grey in panels (c) and (f). Sites with $|\Delta \mathrm{T}|<500$ are shown in (a) and (d), those with $500 \mathrm{yr}<|\Delta \mathrm{T}|<1000 \mathrm{yr}$ in panels (b) and (e), and those with $|\Delta \mathrm{T}|>1000 \mathrm{yr}$ in panels (c) and (f). There are 265, 132, 80 sites in panels (a)-(c) and 336, 113, 28 sites in (d)-(f), respectively. Many data points corresponding to nearby sites overlap, diminishing the apparent difference between the two models. The advantage of the two-source model is nevertheless clear and significant. 
tailed manner for future work. Our formulaic method of attribution has inevitably failed in some cases, but our preliminary checks have confirmed that the results are still broadly consistent with the evidence available, (see below).

First, we considered a model with a single source in the Near East (see Fig. 4a for histogram of time lags). The resulting time lags are presented in Figure $3 \mathrm{a}-\mathrm{c}$. The best fit model with two sources is similarly illustrated in Figure 3d-f. The locations of the two sources are shown with grey ellipses in panels (c) and (f).

In Figure 3a the sites shown are those at which the model arrival date and the radiocarbon date agree within 500 years ( $55 \%$ of the pan-European dates); Figure $3 \mathrm{~d}$ gives a similar figure for the two source model (now $70 \%$ of the pan-European dates fit within 500 years). The points in the EE area are significantly more abundant in Figure $3 d$ than in Figure $3 \mathrm{a}$, while the difference in the SCWE area is less striking. The SCWE sites are better fitted with the one source model, with $|\Delta T|<500$ years for $68 \%$ of data points, but the fit is unacceptably poor for $\mathrm{EE}$, where only $38 \%$ of the radiocarbon dates can be fitted within 500 years. A convenient measure of the quality of the fit is the standard deviation of the time lags

$$
s=\sqrt{\frac{1}{N} \sum_{i=1}^{N}\left(\Delta T_{i}-\overline{\Delta T}\right)} \text { with } \overline{\Delta T}=\frac{1}{N} \sum_{i=1}^{N} \Delta T_{i} .
$$

The standard deviation of the pan-European time lags here is $s=800$ years. Outliers are numerous when all of the European sites are included (illustrated by the abundance of points in Figure 3c), and they make the distribution skewed, and offset from $\Delta T=0$ (see Fig. 4a). The outliers are mainly located in the east: for the SCWE sites, the distribution is more tightly clustered ( $s=540$ years), has negligible mean value, and is quite symmetric. In contrast, the time lags for sites in Eastern Europe (EE), with respect to the centre in the Near East, have a rather flat distribution ( $s=1040$ years), which is strongly skewed and has a significant mean value (310 years).
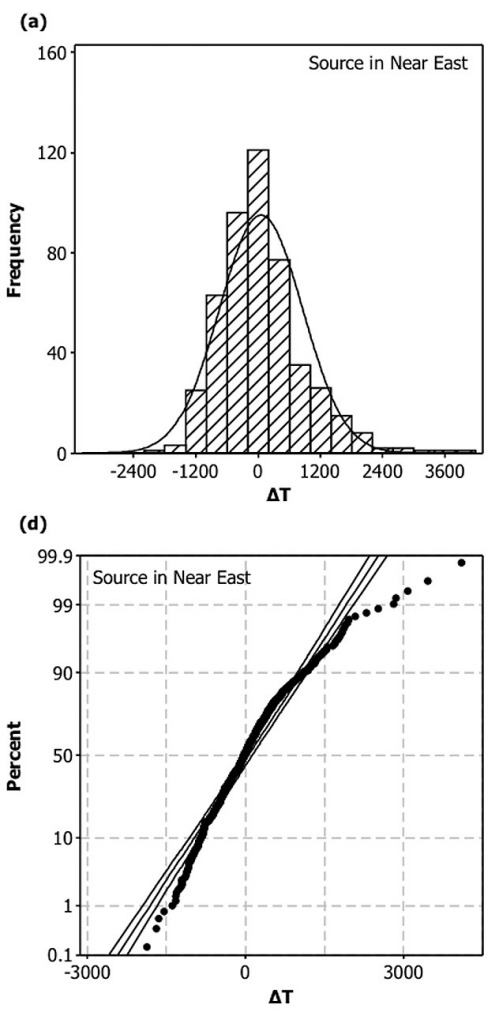

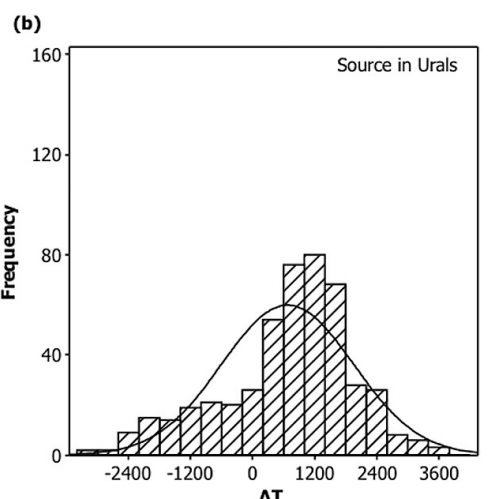

(e)

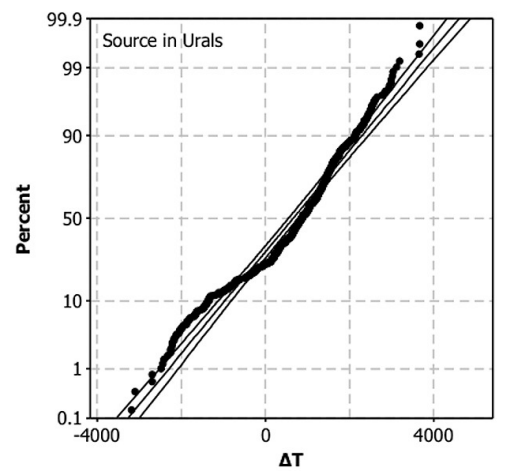

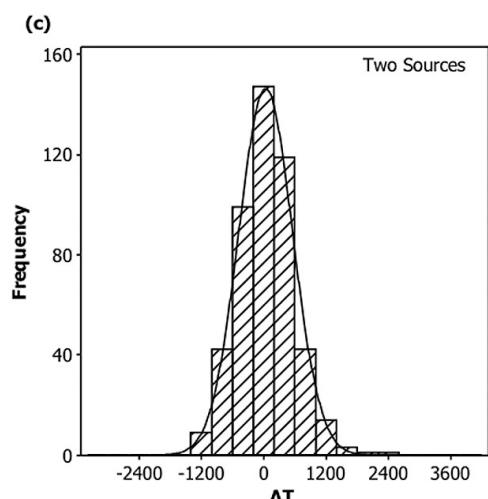

(f)

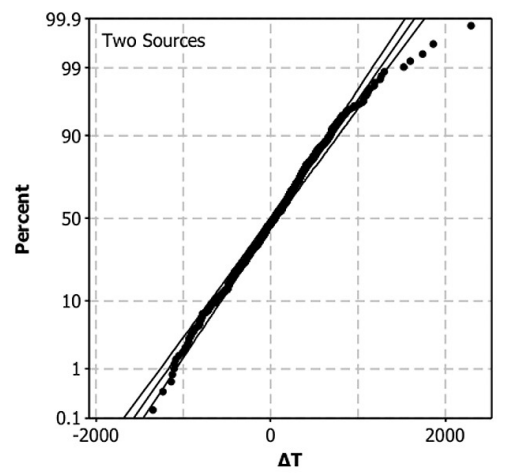

Fig. 4. Time lags, $\Delta \mathrm{T}=\mathrm{T}-\mathrm{T}_{\mathrm{m}}$, between the actual and modelled arrival times for the early Neolithic sites. (a)-(c): Histograms of the time lags, with a normal distribution fit (solid), for a model with a single source in the Near East (a), for a single source in the Urals (b) and for a two-source model (c). (d)-(f): The cumulative probability distribution of the time lags from panels (a)-(c), respectively, rescaled such that a normal probability distribution corresponds to a straight line (known as a normal probability plot). The straight lines show the best-fitting normal distribution, and the $95 \%$ confidence interval. A significant reduction in the number of outliers can be seen in (f) or (c) as compared to (d) or (a) and (e) or (b). The distributions of panels (d) and (e) fail the Anderson-Darling normality test, while (f) passes the test confirming that $\Delta \mathrm{T}$ is normally distributed (p-value $=0.149)$. 
The failure of the single-source model to accommodate the ${ }^{14} \mathrm{C}$ dates from Eastern Europe justifies our use of a more complicated model that has two sources of propagation. Attempts were made at locating the single source in various other locations, such as the Urals, but this did not improve the agreement (see Fig. $4 \mathrm{~b}$ for the histogram of time lags for the model with single source in the Urals).

Adding another source in the East makes the model much more successful: the values of the time lag, shown in Fig. 3d-f, are systematically smaller; i.e. there are significantly fewer points in Fig. $3 \mathrm{f}(5 \%)$ compared to Fig. $3 \mathrm{c}(17 \%)$. The resulting $\Delta T$ distribution for all the sites is quite narrow ( $s=520$ years) and almost perfectly symmetric, with a negligible mean value (40 years), see Fig. 4c. The distributions remain similarly acceptable when calculated separately for each source (with $s=490$ and 570 years for the sites attributable to the Near East and Urals, respectively). The improvement is especially striking in EE, where the sites are split almost equally between the two sources.

We tentatively consider a model acceptable if the standard deviation, $s$, of the time lag $\Delta T$ is not larger than 3 standard dating errors $\sigma$, i.e., about 500 years, given our estimate of $\sigma$ close to 160 years over the pan-European domain. This criterion cannot be satisfied with any single-source model, but is satisfied with two sources. While we would never expect a large-scale model of the sort proposed here to accurately describe the complex process of the Neolithization in fine detail (and so the resulting values of $\Delta T$ cannot be uniformly small), the degree of improvement in terms of the standard deviation of $\Delta T$ clearly favours the two-source model. The reduction in s is statistically significant, and cannot be explained by the increase in the complexity of the model alone. The confidence intervals of the sample standard deviations $s$ for one-source and two-source models do not overlap $(740<\sigma<840$ and $480<\sigma$ $<550$, respectively); the F-test confirms the statistical significance of the reduction at a $99 \%$ level.

It is also instructive to perform some further basic statistical analysis of the time lags $\Delta T$. We use the Anderson-Darling test to assess if the sample of time lags can be approximated by the Gaussian probability distribution (i.e., in particular, have a symmetric distribution with an acceptably small number of outliers). The null hypothesis of the test is that the time lags have a Gaussian distribution with the sample mean and standard deviation, while the alternative hypothesis is that they do not. This test leads us to accept the null hypothesis in the case of the twosource model $(p$-value $=0.149)$ while rejecting the null hypothesis for both one source models. Figure $4 \mathrm{~d}-\mathrm{f}$ show the cumulative probability distributions of the time lags for each model studied, rescaled such that a normal probability distribution corresponds to a straight line (known as a normal probability plot). The straight lines show the best-fitting normal distribution together with its $95 \%$ confidence interval. As quantified by the test, the time lags more closely follow the straight line in (f) than in (d) or (e); the number of outliers is reduced very significantly in (f). Table 1 shows those sites that have $|\Delta T|>$ 1000 years, i.e., where the disagreement between the data and the best-fit, two-source model is the strongest. There are 28 such sites: 14 of these have not undergone any statistical treatment, while the remaining 14 are a result of date combination or selection as described in Section 2. Five of the dates in Table 1 arise from the four sites (Berezovaya, Osipovka, Rakushechnyi Yar and Yerpin Pudas) where we have been unable to isolate less than three representative dates (see Section 2). This may suggest that a reinvestigation of these sites in particular is required and improved stratigraphic and typological data are required for these sites.

As further quantification of the quality of the model, the $\chi^{2}$ statistic has been calculated for each model:

$$
X^{2}=\sum_{i=1}^{N} \frac{\left(\Delta T_{i}\right)^{2}}{\sigma_{i}^{2}} .
$$

The results are shown in Table 2.

The values of $X^{2}$, given in Table 2, may then be compared to the $\chi^{2}$ value at the $5 \%$ level with $N-1$ degrees of freedom $\left(\chi_{N-1}^{2}=527.86\right)$. On all occasions the value of $X^{2}$ significantly exceeds $\chi_{N-1}^{2}$ (at $5 \%$ level) this is not surprising given the simplicity of our model. The $\chi^{2}$ statistical test would be satisfied if we discard about one third of the sites. It should be highlighted however that there is an approximate threefold increase in the accuracy of the model with two sources with respect to a single-source model. Some increase in the fit would be expected since we have increased the complexity of the model, but an increase of this magnitude surpasses what we believe could be attributed simply to the increase in model complexity. Development and application of further statistically robust techniques for comparison of our model with archaeological evidence is subject to our ongoing study. 
Kate Davison, Pavel M. Dolukhanov, Graeme R. Sarson, Anvar Shukurov \& Ganna I. Zaitseva

\begin{tabular}{|c|c|c|c|c|c|c|c|c|c|c|c|c|}
\hline \multirow{2}{*}{ Site Name } & \multirow[b]{2}{*}{ Lab Index } & \multirow[b]{2}{*}{$\begin{array}{l}\text { Lati- } \\
\text { tude } \\
\text { deg. }\end{array}$} & \multirow[b]{2}{*}{$\begin{array}{l}\text { Longi- } \\
\text { tude } \\
\text { deg. }\end{array}$} & \multicolumn{4}{|c|}{ Sample } & \multicolumn{2}{|c|}{ Site } & \multicolumn{3}{|c|}{ Model arrival time } \\
\hline & & & & $\begin{array}{c}\text { Age } \\
\text { BP } \\
\text { yr }\end{array}$ & Error & $\begin{array}{c}\text { Age } \\
\text { cal BC } \\
\text { yr }\end{array}$ & $\begin{array}{l}\text { Calib- } \\
\text { ration } \\
\text { Error }\end{array}$ & $\begin{array}{c}\text { Age } \\
\text { cal BC } \\
\text { yr }\end{array}$ & $\begin{array}{l}\text { Calib- } \\
\text { ration } \\
\text { Error }\end{array}$ & Note & $\begin{array}{c}\text { From } \\
\text { Near } \\
\text { East, } \\
\text { yr BC }\end{array}$ & $\begin{array}{c}\text { From } \\
\text { Urals, } \\
\text { yr BC }\end{array}$ \\
\hline Argisa Magula & UCLA-1657A & 39.64 & 22.47 & 8130 & 100 & 7100 & 400 & 7100 & 400 & One date & 6052 & 3975 \\
\hline Balma Margineda & Ly-2439 & 42.41 & 1.58 & 6670 & 85 & 5600 & 130 & 5600 & 130 & One date & 6700 & 3256 \\
\hline Bavans & LV-1415 & 47.47 & 6.70 & 7130 & 70 & 6000 & 170 & 6000 & 170 & One date & 4903 & 3777 \\
\hline Berezovaya & LE-6706a & 60.38 & 44.17 & 7840 & 75 & 6775 & 92 & 6775 & 92 & Older date & 3697 & 5509 \\
\hline Berezovaya & LE-67066 & 60.38 & 44.17 & 8700 & 300 & 7800 & 267 & 7800 & 267 & Oldest date & 3697 & 5509 \\
\hline Bolshoe Zavetnoye & LE-6556 & 60.98 & 29.63 & 7750 & 180 & 6650 & 150 & 6650 & 150 & Oldest date & 3836 & 4913 \\
\hline Canhasan III & BM-1666R & 37.50 & 33.50 & 8460 & 150 & 7450 & 133 & 7338 & 233 & Chi-Squared & 5814 & 3664 \\
\hline Canhasan III & BM-1664R & & & 8470 & 140 & 7450 & 133 & & & & & \\
\hline Canhasan III & BM-166oR & & & 8390 & 140 & 7375 & 108 & & & & & \\
\hline Canhasan III & BM-1667R & & & 8480 & 110 & 7450 & 100 & & & & & \\
\hline Canhasan III & BM-1662R & & & 8460 & 110 & 7450 & 100 & & & & & \\
\hline Canhasan III & BM-1663R & & & 8350 & 210 & 7300 & 233 & & & & & \\
\hline Canhasan III & BM-1665R & & & 8270 & 160 & 7200 & 133 & & & & & \\
\hline Canhasan III & BM-1656R & & & 8090 & 170 & 7050 & 150 & & & & & \\
\hline Canhasan III & $\mathrm{HU}-12$ & & & 8543 & 66 & 7600 & 40 & & & & & \\
\hline Canhasan III & BM-1658R & & & 8060 & 130 & 7025 & 142 & & & & & \\
\hline Canhasan III & HU-11 & & & 8584 & 65 & 7635 & 38 & & & & & \\
\hline Canhasan III & BM-1657R & & & 8080 & 130 & 7050 & 133 & & & & & \\
\hline Carrowmore & Lu-1840 & 54.27 & -8.53 & 5750 & 85 & 4575 & 215 & 4575 & 215 & One date & 3517 & 2445 \\
\hline Cashelkeelty & UB-2413 & 51.72 & -9.82 & 5845 & 100 & 4695 & 245 & 4695 & 245 & One date & 3585 & 2267 \\
\hline Choinovtyi- & LE-5164 & 64.42 & 49.95 & 4640 & 25 & 3435 & 28 & 4070 & 595 & $\begin{array}{l}\text { Average of } \\
\text { site one }\end{array}$ & 2963 & 5374 \\
\hline Choinovtyi-1 & LE-1729 & & & 5320 & 60 & 4160 & 57 & & & & & \\
\hline Choinovtyi-1 & LE-4495 & & & 5750 & 70 & 4615 & 55 & & & & & \\
\hline DobriniöËe & Bln-3785 & 41.83 & 23.57 & 6650 & 60 & 5575 & 32 & 5575 & 32 & One date & 6700 & 4199 \\
\hline Dubokrai-5 & Le-3003 & 55.85 & 30.37 & 4720 & 40 & 3505 & 45 & 3578 & 160 & $\begin{array}{l}\text { Average of } \\
\text { middle peak }\end{array}$ & 4628 & 5025 \\
\hline Dubokrai-6 & Le-6279 & & & 4820 & 130 & 3650 & 117 & & & & & \\
\hline Golubjai-1 & LE-4714 & 54.95 & 22.98 & 7060 & 270 & 5950 & 167 & 5950 & 167 & Older date & 4577 & 4703 \\
\hline Grotta del Sant & R-284 & 40.90 & 15.78 & 5555 & 75 & 4395 & 155 & 4395 & 155 & One date & 5722 & 3326 \\
\hline \multicolumn{13}{|l|}{ della Madonna } \\
\hline $\begin{array}{l}\text { Grotta di Porto } \\
\text { Badisco }\end{array}$ & R-1225 & 40.08 & 18.48 & 5850 & 55 & 4675 & 135 & 4675 & 135 & One date & 5815 & 3452 \\
\hline Kamennaya Mogila & $\mathrm{Ki}-4 \mathrm{O} 23$ & 47.20 & 35.35 & 5120 & 80 & 3975 & 92 & 3975 & 92 & Younger date & 5675 & 4984 \\
\hline Koshinskaya & LE-6629 & 57.63 & 48.23 & 8350 & 100 & 7360 & 73 & 7360 & 73 & Older date & 3896 & 5767 \\
\hline Kurkijokki & LE-6929 & 60.18 & 29.88 & 7900 & 80 & 6825 & 75 & 6825 & 75 & One date & 3973 & 4963 \\
\hline Marevka & OxA-6199 & 48.35 & 35.30 & 7955 & 55 & 6865 & 62 & 6865 & 62 & Older date & 5566 & 5042 \\
\hline Osipovka & OxA-6168 & 49.93 & 30.40 & 7675 & 70 & 6535 & 38 & 6535 & 38 & Older date & 5473 & 4896 \\
\hline Planta & CRG-280 & 46.23 & 7.37 & 6500 & 80 & 5465 & 155 & 5465 & 155 & One date & 6700 & 3697 \\
\hline $\begin{array}{l}\text { Racquemissou } \\
\text { VIII cl }\end{array}$ & & 44.42 & 2.73 & 7400 & 300 & 6400 & 233 & 6400 & 233 & One date & 5209 & 3445 \\
\hline Rakushechnyi Yar & Le-5387 & 47.55 & 40.67 & 4830 & 90 & 3585 & 72 & 3862 & 283 & $\begin{array}{l}\text { Average of } \\
\text { younger cluster }\end{array}$ & 5417 & 5209 \\
\hline Rakushechnyi Yar & Le- 5340 & & & 5060 & 230 & 3850 & 183 & & & & & \\
\hline Rakushechnyi Yar & Le-5327 & & & 5290 & 260 & 4150 & 217 & & & & & \\
\hline Rakushechnyi Yar & Le-5344 & 47.55 & 40.67 & 7180 & 250 & 6050 & 167 & 6600 & 319 & \begin{tabular}{|l|}
$\begin{array}{l}\text { Average from } \\
\text { older cluster }\end{array}$ \\
\end{tabular} & 5417 & 5209 \\
\hline Rakushechnyi Yar & Ki-6475 & & & 7690 & 100 & 6600 & 83 & & & & & \\
\hline Rakushechnyi Yar & Ki-955 & & & 7840 & 105 & 6750 & 100 & & & & & \\
\hline Rakushechnyi Yar & Ki-6477 & & & 7860 & 130 & 6775 & 108 & & & & & \\
\hline Rakushechnyi Yar & Ki-6476 & & & 7930 & 140 & 6825 & 125 & & & & & \\
\hline Saliagos & P-1311 & 37.05 & 25.08 & 6172 & 74 & 5080 & 230 & 5080 & 230 & One date & 6165 & 3471 \\
\hline Serteya-10 & Le- 5260 & 56.22 & 31.57 & 7350 & 180 & 6200 & 133 & 6225 & 317 & $\begin{array}{l}\text { Average of } \\
\text { older dates }\end{array}$ & 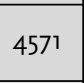 & 5081 \\
\hline Serteya-10 & Le- 5261 & & & 7300 & 400 & 6250 & 317 & & & & & \\
\hline Theopetra Cave & DEM.576 & 39.68 & 21.68 & 8060 & 32 & 6980 & 53 & 6980 & 53 & One date & 5969 & 3980 \\
\hline Zapes & Vs-977 & 54.08 & 23.67 & 4860 & 260 & 3600 & 233 & 3600 & 233 & One date & 4708 & 4716 \\
\hline
\end{tabular}


It is instructive to represent the data in the same format as in Figure $2 a, b$, but now with each date attributed to one of the sources, as suggested by our model. This has been done in Figure $2 c$, d, where the close correlation of Figure $2 a$ is restored for the panEuropean data. Now, the dates are consistent with constant rates of spread from one of the two sources. Using straight-line fitting, we obtain the average speed of the front propagation of $1.1 \pm 0.1 \mathrm{~km} / \mathrm{year}$ for the wave originating in the Near East (Fig. 2c), and $1.7 \pm 0.3 \mathrm{~km} /$ year for the source in the East (Fig. $2 \mathrm{~d}) ; 2 \sigma$ values are given as uncertainties here and below. The spread from the Near East slowed down in Eastern Europe to $0.7 \pm 0.1 \mathrm{~km} /$ year; the dates from the west alone (as in Fig. 2a) gives a higher speed of $1.2 \pm 0.1 \mathrm{~km} /$ year. The estimates for the data in both western and eastern Europe are compatible with earlier results (Dolukhanov et al. 2005; Gkiasta et al. 2003; Pinhasi et al. 2005). Care must be taken when using such estimates, however, since the spread occurs in a strongly heterogeneous space, and so cannot be fully characterised by a single constant speed. The rate of spread varies on both panEuropean scale and on smaller scales, e.g., near major waterways (Davison et al. 2006).

Our allocation of sites to sources suggested and used above requires careful verification using independent evidence. Here we briefly discuss a few sites. Taking Ivanovskoye-2 $\left(56.85^{\circ} \mathrm{N}, 39.03^{\circ} \mathrm{E}\right)$ as an example, the data form two peaks (Fig. 1b); the times at which each of the waves arrive at this location are 4349 BC (for the Near-Eastern wave) and 5400 BC (for the Eastern wave) closely fitting the two peaks in ${ }^{14} \mathrm{C}$ dates. As another example, we accept two dates for the Mayak site $\left(68.45^{\circ} \mathrm{N}, 38.37^{\circ} \mathrm{E}\right)$; one from the younger cluster $(2601 \pm 192 \mathrm{BC}$ ), and also the older date $(4590 \pm 47 \mathrm{BC})$ detached from the cluster. The younger cluster is consistent with the near-eastern wave (arriving at $2506 \mathrm{BC}$ ) and the older date with the Eastern wave (arriving at $4718 \mathrm{BC}$ ).

Tab. 1 (on previous page). The 28 sites where the deviation of the model arrival times from the ${ }^{14} \mathrm{C}$ dates exceeds 1000 years, $\mid \Delta \mathrm{T} />1000$ years: (1) site name; (2) laboratory index; geographical (3) latitude and (4) longitude in degrees; (5) uncalibrated age and (6) its $1 \sigma$ laboratory error in years (BP); (7) calibrated age and (8) its $1 \sigma$ error in years (BC); (9) combined site calibrated age and (10) its 16 error in years (BC) obtained as discussed in Section 2; (11) method used to select this date; and the model arrival times (years BC) for the wave spreading from (12) the Near East and (13) the Urals. The data are presented in alphabetical site name order.

\begin{tabular}{|lc|}
\hline Model & $\mathbf{X}^{\mathbf{2}}$ \\
\hline Single source in Near-East & 9553 \\
\hline Single source in Urals & 28268 \\
\hline Two-source model & 3740 \\
\hline
\end{tabular}

Tab. 2. The $\mathrm{X}^{2}$ test statistic, given by Eq. (4), for each model.

We further consider those sites which are geographically in the west (i.e., to the west of a boundary set to join the Baltic Sea to the Black Sea) but are allocated to the source of pottery making in the Ural mountain area. These sites are shown in Table 3. There are 40 such sites (i.e., $14 \%$ of sites in the west); they deserve further analysis in order to verify the attribution suggested by the model and, if necessary, to further refine the model to improve the agreement with the archaeological data. There are also 104 sites in the east of the above boundary that are allocated to the source of farming in the Near East (i.e. $56 \%$ of data points in the east). These sites are listed in Table 4. Where a site is characterised by a combined date obtained as described above, only the final age estimate is given (see entry in the column labelled 'Note' for the selection technique applied). All sites in Tables 3 and 4 should be reassessed both in terms of the statistical processing of multiple measurements and in terms of the agreement with independent archaeological data.

\section{Conclusions}

Our model has significant implications for the understanding of the Neolithization of Europe. It substantiates our suggestion that the spread of the Neolithic involved at least two waves propagating from distinct centres, starting at about $8200 \mathrm{BC}$ in Eastern Europe and $6700 \mathrm{BC}$ in the Near East. The earlier wave, spreading from the east via the 'steppe corridor', resulted in the establishment of the 'eastern version' of the Neolithic in Europe. A later wave, originating in the Fertile Crescent of the Near East, is the better-studied process that brought farming to Europe.

It is conceivable that the westernmost extension of the earlier (eastern) wave of advance produced the pre-agricultural ceramic sites of La Hoguette type in north-eastern France and western Germany, and Roucadour-type (also known as Epicardial) sites in western Mediterranean and Atlantic France (Berg and Hauzer 2001; Jeunesse 1987). The available dates for the earlier Roucadour sites (7500-6500 BC) (Roussault-Laroque 1990) are not inconsistent with 


\begin{tabular}{|c|c|c|c|c|c|c|c|c|c|}
\hline \multirow[b]{2}{*}{ Site Name } & \multirow[b]{2}{*}{ Lab index } & \multirow[b]{2}{*}{$\begin{array}{l}\text { Lati- } \\
\text { tude } \\
\text { deg. }\end{array}$} & \multirow[b]{2}{*}{$\begin{array}{l}\text { Longi- } \\
\text { tude } \\
\text { deg. }\end{array}$} & \multicolumn{4}{|c|}{ Sample } & \multicolumn{2}{|c|}{ Model arrival time } \\
\hline & & & & $\begin{array}{c}\text { Age } \\
\text { BP, } \\
\text { yr }\end{array}$ & Error & $\begin{array}{c}\text { Age } \\
\text { cal BC, } \\
\text { yr }\end{array}$ & $\begin{array}{c}\text { Calibra- } \\
\text { tion } \\
\text { Error }\end{array}$ & $\begin{array}{c}\text { From } \\
\text { Near East, } \\
\text { yr BC }\end{array}$ & $\begin{array}{l}\text { From } \\
\text { Urals, } \\
\text { yr BC }\end{array}$ \\
\hline Abri de la Coma Franceze & Gif-9o8o & 42.83 & 2.92 & 5180 & 60 & 4010 & 220 & 5338 & 3327 \\
\hline Bridgemere & BM-2565 & 51.21 & -2.41 & 4630 & 50 & 3375 & 275 & 4291 & 3156 \\
\hline Burntwood Farm. R6 & OxA-1384 & 51.12 & -1.29 & 4750 & 50 & 3510 & 140 & 4324 & 3232 \\
\hline Bury Hill & & 50.92 & -1.37 & 4750 & 50 & 3510 & 140 & 4343 & 3223 \\
\hline Chatelliers du Viel & Gif-5717 & 46.43 & -0.87 & 5200 & 110 & 4025 & 325 & 4829 & 3402 \\
\hline Cherhill & BM-493 & 51.43 & -1.95 & 4715 & 90 & 3400 & 300 & 4276 & 3186 \\
\hline Coma Franceze & Gif-7292 & 42.83 & 2.92 & 5200 & 70 & 4025 & 225 & 5338 & 3327 \\
\hline Corhampton & BM-1889 & 50.98 & -1.15 & 4790 & 70 & 3535 & 165 & 4334 & 3237 \\
\hline Coufin & Ly-3321 & 45.07 & 5.40 & 5260 & 120 & 4050 & 300 & 5188 & 3565 \\
\hline Derriere les Pres & WM & 49.07 & -0.05 & 5110 & 70 & 4030 & 320 & 4576 & 3502 \\
\hline Feldbach & UCLA-1809A & 47.23 & 8.78 & 5170 & 70 & 4010 & 220 & 4998 & 3861 \\
\hline Fendmeilen & UCLA-1691F & 47.28 & 8.63 & 5415 & 60 & 4200 & 160 & 4998 & 3857 \\
\hline Fengate & GaK-4196 & 52.57 & -0.21 & 4960 & 64 & 3145 & 225 & 4198 & 3200 \\
\hline Frankenau & VRI-207 & 47.50 & 16.50 & 5660 & 100 & 4525 & 125 & 5377 & 4213 \\
\hline Frigouras & GIF-8479 & 44.13 & 5.95 & 5450 & 100 & 4250 & 210 & 5341 & 3506 \\
\hline Grande Louvre & GIF-7618 & 48.87 & 2.33 & 5260 & 70 & 4105 & 155 & 4612 & 3619 \\
\hline Greifensee & WM & 47.37 & 8.68 & 5140 & 49 & 3920 & 130 & 5010 & 3861 \\
\hline Grotta dei Ciclami & WM & $45 \cdot 70$ & 4.92 & 5445 & 60 & 4245 & 205 & 5114 & 3597 \\
\hline Grotta del Sant della Madonna & $\mathrm{R}-284$ & 40.90 & 15.78 & 5555 & 75 & 4395 & 155 & 5722 & 3326 \\
\hline Grotte de la Vieille Eglise & WM & 45.92 & 6.28 & 5295 & 52 & 4115 & 135 & 5018 & 3657 \\
\hline Grotte du Sanglier & WM & 44.68 & 5.33 & 5440 & 130 & 4250 & 300 & 5268 & 3531 \\
\hline Honeygore Track & GaK-1939 & 51.18 & -2.82 & 4590 & 40 & 3305 & 205 & 4298 & 3130 \\
\hline Horné Lefantovce & Bln-304 & 48.42 & 18.17 & 5775 & 140 & 4700 & 200 & 5396 & 4318 \\
\hline Le Coq Galleux & WM & 49.40 & 2.73 & 5300 & 140 & 4100 & 350 & 4554 & 3652 \\
\hline Le Trou du Diable & Ly-6505 & 47.32 & 4.78 & 5105 & 55 & 3905 & 135 & 4870 & 3682 \\
\hline Les Coudoumines & WM & 42.75 & 2.57 & 5135 & 36 & 3920 & 120 & 5309 & 3315 \\
\hline Les Longrais & Ly-150 & 46.58 & 2.77 & 5290 & 150 & 4100 & 167 & 4898 & 3561 \\
\hline Mannlefelsen & Gif-2634 & 47.45 & 7.23 & 5140 & 140 & 3950 & 300 & 4954 & 3800 \\
\hline Millbarrow & OxA-3172 & 51.45 & -1.87 & 4900 & 110 & 3675 & 325 & 4277 & 3191 \\
\hline Peak Camp & OxA-1622 & 51.83 & -2.15 & 4865 & 80 & 3650 & 300 & 4224 & 3163 \\
\hline Phyn & WM & 47.58 & 8.93 & 4993 & 28 & 3820 & 120 & 5029 & 3883 \\
\hline Redlands Farm & OxA-5632 & 52.33 & -0.59 & 4825 & 65 & 3545 & 165 & 4209 & 3211 \\
\hline Sente Saillancourt & Gif-5840 & 49.08 & 2.00 & 5220 & 110 & 4050 & 300 & 4569 & 3609 \\
\hline Shurton Hill & UB-2122 & 50.92 & -0.58 & 4750 & 50 & 3510 & 140 & 4346 & 3282 \\
\hline Source de Reselauze & WM & 43.52 & 4.98 & 5380 & 110 & 4210 & 240 & 5424 & 3460 \\
\hline Windmill Hill & OxA-2395 & 50.92 & -1.88 & 4730 & 80 & 3505 & 155 & 4335 & 3183 \\
\hline Winnall Down & HAR-2196 & 51.08 & -1.32 & 4800 & 80 & 3540 & 180 & 4324 & 3226 \\
\hline Zurich & UCLA-1772B & 47.37 & 8.58 & 5145 & 70 & 3975 & 275 & 5010 & 3857 \\
\hline Zurich-Bauschanze & WM & 47.41 & 8.52 & 5320 & 60 & 4155 & 175 & 5018 & 3857 \\
\hline Zurich-Wollishofen & WM & 47.41 & 8.52 & 4993 & 46 & 3805 & 145 & 5018 & 3857 \\
\hline
\end{tabular}

Tab. 3. The 40 sites which are allocated to the source of spread in the Urals but are located to the west of a west-east borderline joining the Baltic Sea to the Black Sea: (1) site name; (2) laboratory index; geographical (3) latitude and (4) longitude in degrees; (5) uncalibrated age and (6) it's $1 \sigma$ laboratory error in years (BP); (7) calibrated age and (8) it's 16 error in years (BC); and the model arrival times (years BC) for the wave spreading from (9) the Near East and (10) the Urals. The data are presented in alphabetical site name order. 


\begin{tabular}{|c|c|c|c|c|c|c|c|}
\hline \multirow{2}{*}{ Site Name } & \multirow[b]{2}{*}{$\begin{array}{l}\text { Lati- } \\
\text { tude } \\
\text { deg. }\end{array}$} & \multirow[b]{2}{*}{$\begin{array}{l}\text { Longi- } \\
\text { tude } \\
\text { deg. }\end{array}$} & \multicolumn{2}{|c|}{ Site } & \multirow[b]{2}{*}{ Note } & \multicolumn{2}{|c|}{ Model arrival time } \\
\hline & & & $\begin{array}{c}\text { Age } \\
\text { cal BC, } \\
\text { yr }\end{array}$ & $\begin{array}{l}\text { Calibra- } \\
\text { tion } \\
\text { Error }\end{array}$ & & $\begin{array}{c}\text { From Near } \\
\text { East, } \\
\text { yr BC }\end{array}$ & \begin{tabular}{|l|} 
From \\
Urals, \\
yr BC \\
\end{tabular} \\
\hline Babshin & 48.47 & 26.57 & 5160 & 50 & One date & 5518 & 4680 \\
\hline Bara & 60.00 & 40.15 & 2900 & 150 & One date & 3884 & 5386 \\
\hline Bazkov Isle & 48.08 & 28.47 & 5568 & 160 & Average of the younger cluster & 5660 & 4745 \\
\hline Bazkov Isle & 48.08 & 28.47 & 6143 & 160 & Average of the older cluster & 5660 & 4745 \\
\hline Berendeevo-2a & 56.57 & 39.17 & 3883 & 187 & Average of middle peak & 4376 & 5408 \\
\hline Bernashovka & 48.55 & 27.50 & 5565 & 212 & Average of older cluster & 5552 & 4722 \\
\hline Besovy Sledki & 64.38 & 34.43 & 3190 & 60 & Younger date & 3310 & 4993 \\
\hline Besovy Sledki & 64.38 & 34.43 & 4010 & 205 & Average of older three dates & 3310 & 4993 \\
\hline Bilshivtsy & 48.93 & 24.58 & 5307 & 160 & Average & 5353 & 4610 \\
\hline Chapaevka & 47.30 & 35.52 & 5853 & 160 & Average & 5663 & 5000 \\
\hline Chernaya Guba-4 & 62.82 & 34.87 & 3414 & 316 & Average of younger cluster & 3558 & 5104 \\
\hline Chernushka-1 & 57.68 & 48.77 & 3995 & 276 & Average & 3875 & 5784 \\
\hline Choinovtyi -2 & 64.30 & 49.87 & 3668 & 11 & One date & 2977 & 5379 \\
\hline Choinovtyi-1 & 64.42 & 49.95 & 4070 & 595 & Average of site one & 2963 & 5374 \\
\hline Daktariske & 55.82 & 22.87 & 4350 & 100 & Oldest date & 4454 & 4707 \\
\hline Drozdovka & 68.33 & 38.28 & 1535 & 52 & One date & 2510 & 4716 \\
\hline Dubokrai-5 & 55.85 & 30.37 & 3578 & 160 & Average of middle peak & 4628 & 5025 \\
\hline Dubokrai-5 & 55.85 & 30.37 & 4700 & 600 & Oldest Date & 4628 & 5025 \\
\hline Gard-3 & 47.70 & 31.20 & 5722 & 160 & Average & 5800 & 4839 \\
\hline Ivanovskoye-2 & 56.85 & 39.03 & 4094 & 201 & Weighted average of younger peak. $X^{2}$ & 4349 & 5400 \\
\hline Kääpa & 57.87 & 27.10 & 3509 & 217 & Average of older cluster & 4299 & 4898 \\
\hline Kamennaya Mogila & 47.20 & 35.35 & 5717 & 460 & Average of older cluster & 5675 & 4984 \\
\hline Kizilevyj-5 & 48.25 & 35.15 & 5640 & 53 & One date & 5580 & 5031 \\
\hline Kodrukōla & 59.45 & 28.08 & 3590 & 160 & Average & 4081 & 4929 \\
\hline Korman & 48.57 & 27.23 & 5193 & 160 & Average & 5541 & 4712 \\
\hline Koshinskaya & 57.63 & 48.23 & 3550 & 167 & Younger Date & 3896 & 5767 \\
\hline Krivina-3 & 54.95 & 29.63 & 4145 & 58 & Older date & 4755 & 4986 \\
\hline Krivun & 68.28 & 38.43 & 2685 & 65 & Younger date & 2518 & 4726 \\
\hline Krivun & 68.28 & 38.43 & 3375 & 92 & Older date & 2518 & 4726 \\
\hline Kuzomen & 66.27 & 36.77 & 2100 & 200 & One date & 2733 & 4791 \\
\hline Lanino-2 & 57.18 & 33.00 & 4779 & 533 & Average of older cluster & 4431 & 5144 \\
\hline Lasta -8 & 64.77 & 53.73 & 2690 & 70 & One date & 2780 & 5381 \\
\hline Lasta -8 & 64.77 & 53.73 & 3500 & 267 & One date & 2780 & 5381 \\
\hline Maieri-2 & 61.88 & 30.57 & 2975 & 725 & One Date & 3657 & 4971 \\
\hline Mamai Gora & 47.47 & 34.38 & 5940 & 160 & Average & 5664 & 4964 \\
\hline Marevka & 48.35 & 35.30 & 6477 & 167 & Average & 5566 & 5042 \\
\hline Marevka & 48.35 & 35.30 & 6865 & 62 & One date & 5566 & 5042 \\
\hline Mariupol Cemetry & 47.15 & 37.57 & 5518 & 160 & Average & 5636 & 5075 \\
\hline Marmuginsky & 60.80 & 46.30 & 3500 & 47 & One date & 3564 & 5554 \\
\hline Mayak & 68.45 & 38.37 & 2601 & 192 & Weighted average. $X^{2}$ & 2506 & 4718 \\
\hline Modlona & 60.35 & 38.80 & 3067 & 575 & Average & 3873 & 5327 \\
\hline Mys-7 & 67.98 & 34.97 & 2660 & 63 & Older date & 2665 & 4685 \\
\hline Navolok & 66.50 & 40.58 & 2975 & 125 & Younger date & 2777 & 4922 \\
\hline Navolok & 66.50 & 40.58 & 3575 & 68 & Older date & 2777 & 4922 \\
\hline Nerpichya Guba & 68.37 & 38.38 & 2275 & 108 & Younger date & 2506 & 4718 \\
\hline Nerpichya Guba & 68.37 & 38.38 & 3325 & 108 & Older date & 2506 & 4718 \\
\hline Okopy & 49.97 & 26.53 & 5458 & 223 & Average & 5334 & 4730 \\
\hline Orovnavolok & 62.77 & 35.08 & 2790 & 33 & One date & 3570 & 5116 \\
\hline Ortinokh-2 & 68.05 & 54.13 & 2035 & 55 & One date & 2317 & 5132 \\
\hline Osa & 56.85 & 24.58 & 4434 & 435 & Average of middle cluster & 4380 & 4795 \\
\hline Oshchoy - 2 & 63.77 & 48.58 & 3230 & 47 & One date & 3099 & 5406 \\
\hline Osipovka & 49.93 & 30.40 & 6535 & 38 & One Date & 5473 & 4896 \\
\hline Osipovsky Liman & 48.87 & 34.92 & 6400 & 57 & One date & 5514 & 5047 \\
\hline Pechora & 48.83 & 28.70 & 6117 & 160 & Average & 5573 & 4782 \\
\hline
\end{tabular}




\begin{tabular}{|c|c|c|c|c|c|c|c|}
\hline Pegrema-3 & 62.58 & 34.43 & 3433 & 506 & Average of younger cluster & 3598 & 5099 \\
\hline Pleshcheyevo-3 & 56.78 & 38.70 & 3505 & 45 & Oldest date & 4371 & 5386 \\
\hline Povenchanko-15 & 62.82 & 34.85 & 2875 & 72 & One date & 3558 & 5104 \\
\hline Pugach-2 & 47.85 & 31.23 & 5633 & 160 & Average of older cluster & 5780 & 4850 \\
\hline Pyalitsa-18 & 66.18 & 39.83 & 3500 & 47 & One date & 2823 & 4945 \\
\hline Rakushechnyi Yar & 47.55 & 40.67 & 5456 & 333 & Average from middle cluster & 5417 & 5209 \\
\hline Rakushechnyi Yar & 47.55 & 40.67 & 6600 & 319 & Average from older cluster & 5417 & 5209 \\
\hline Razdolnoye & 47.60 & 38.03 & 5475 & 160 & Average & 5571 & 5112 \\
\hline Repishche & 58.35 & 33.88 & 3313 & 160 & One Date & 4252 & 5176 \\
\hline Rudnya Serteyskaya & 55.63 & 31.57 & 4381 & 233 & Chi-Squared & 4656 & 5077 \\
\hline Sakhtysh-8 & 56.80 & 40.47 & 4068 & 189 & Weighted average & 4296 & 5465 \\
\hline Sarnate & 57.33 & 21.53 & 3290 & 233 & Average & 4201 & 4639 \\
\hline Savran & 48.12 & 30.02 & 5853 & 160 & Average & 5720 & 4808 \\
\hline Semenovka & 48.28 & 30.13 & 5863 & 262 & Average & 5702 & 4822 \\
\hline Semenovka-5 & 45.42 & 29.50 & 5455 & 179 & Average & 5979 & 4615 \\
\hline Serteya-10 & 56.22 & 31.57 & 3688 & 200 & Ave of young dates (exc. Corded) & 4571 & 5081 \\
\hline Sev. Salma & 68.03 & 35.18 & 3050 & 483 & One date & 2661 & 4687 \\
\hline Sheltozero-10 & 61.35 & 35.35 & 3000 & 117 & Youngest date & 3791 & 5173 \\
\hline Silino & 60.85 & 29.73 & 3820 & 160 & Average of younger cluster & 3865 & 4919 \\
\hline Skibinsky & 48.57 & 29.35 & 6303 & 160 & Average & 5631 & 4801 \\
\hline Sokoltsy-2 & 48.72 & 29.12 & 6253 & 160 & Average & 5600 & 4796 \\
\hline Spiginas & 56.02 & 21.85 & 3850 & 167 & Older date & 4393 & 4670 \\
\hline Sukhaya Vodla-2 & 62.40 & 37.10 & 3540 & 57 & One date & 3604 & 5194 \\
\hline Sulka & 56.75 & 27.00 & 3890 & 346 & Average of middle cluster & 4452 & 4891 \\
\hline Suna-12 & 62.10 & 34.22 & 4005 & 75 & One Date & 3677 & 5108 \\
\hline Surskoi Isle & 48.32 & 35.07 & 6110 & 160 & Average & 5570 & 5032 \\
\hline Šventoji 9 & 56.02 & 21.08 & 3950 & 100 & Oldest date & 4354 & 4653 \\
\hline Syaberskoye-3 & 58.78 & 29.10 & 3750 & 217 & Older date & 4193 & 4975 \\
\hline Tamula & 57.85 & 26.98 & 4150 & 60 & Oldest date & 4298 & 4894 \\
\hline Tekhanovo & 57.07 & 39.28 & 4100 & 47 & One date & 4308 & 5409 \\
\hline Tokarevo & 60.50 & 28.77 & 3450 & 183 & One date & 3883 & 4904 \\
\hline Tugunda-14 & 64.37 & 33.30 & 2848 & 160 & Average & 3324 & 4974 \\
\hline Vashutinskaya & 57.37 & 40.13 & 3835 & 45 & Yougest date & 4243 & 5445 \\
\hline Vodysh & 58.13 & 41.53 & 3275 & 125 & One date & 4087 & 5487 \\
\hline Voynavolok-24 & 62.90 & 34.57 & 2838 & 160 & Average of younger cluster & 3546 & 5092 \\
\hline Voynavolok-24 & 62.90 & 34.57 & 3115 & 72 & Older date & 3546 & 5092 \\
\hline Vozhmarikha -4 & 63.33 & 35.78 & 3620 & 160 & Average of younger cluster & 3477 & 5113 \\
\hline Vyborg & 60.67 & 28.65 & 3260 & 80 & One date & 3855 & 4893 \\
\hline Yazykovo-1a & 57.27 & 33.37 & 4700 & 177 & Chi Squared & 4416 & 5157 \\
\hline Yerpin Pudas & 63.35 & 34.48 & 4175 & 160 & Average of yougest cluster & 3482 & 5072 \\
\hline Yumizh-1 & 62.23 & 44.35 & 3000 & 221 & Average & 3446 & 5416 \\
\hline Zalavruga-4 & 62.80 & 36.47 & 3333 & 286 & Average of older cluster & 3547 & 5159 \\
\hline Zapes & 54.08 & 23.67 & 3600 & 233 & One date & 4708 & 4716 \\
\hline Zarachje & 56.15 & 38.63 & 4515 & 52 & One date & 4448 & 5387 \\
\hline Zatsen'ye & 54.40 & 27.07 & 4255 & 68 & One date & 4778 & 4868 \\
\hline Zedmar-D & 54.37 & 22.00 & 3898 & 250 & Weighted average. $\mathrm{X}^{2}$ & 4607 & 4651 \\
\hline Zejmatiške & 55.25 & 26.15 & 4355 & 38 & Oldest date & 4640 & 4841 \\
\hline Zolotets-6 & 62.78 & 36.53 & 3688 & 442 & Average of older cluster & 3560 & 5162 \\
\hline Zveisalas & 57.83 & 27.25 & 3730 & 70 & One date & 4302 & 4904 \\
\hline Zvejnieki & 57.82 & 25.17 & 4211 & 273 & Average of younger cluster & 4257 & 4824 \\
\hline
\end{tabular}

Tab. 4 (beginning on previous page). The 104 sites which are allocated to the source of spread in the Near East but are located to the east of a west-east borderline joining the Baltic Sea to the Black Sea: (1) site name; geographical (2) latitude and (3) longitude in degrees; (4) calibrated age and (5) its $1 \sigma$ error in years (BC); (6) method used to select this date; and the model arrival times (years BC) for the wave spreading from (7) the Near East and (8) the Urals. For sites with multiple ${ }^{14}$ C dates only one (or a few) representative dates are given, obtained as discussed in Section 2. The selection method applied is given in the column labelled Note. The data are presented in alphabetical site name order. 
this idea, but a definitive conclusion needs additional work.

The nature of the eastern source needs to be further explored. The early-pottery sites of the Yelshanian Culture (Mamonov 2000) have been identified in a vast steppe area stretching between the Lower Volga and the Ural Rivers. The oldest dates from that area are about $8000 \mathrm{BC}$ (although the peak of the culture occurred 1000 years later) (Dolukhanov et al. 2005). Even earlier dates have been obtained for pottery bearing sites in Southern Siberia and the Russian Far East (Kuzmin and Orlova 2000; Timofeev et al. 2004). This empirical relation between our virtual eastern source and the earlier pottery-bearing sites further east may indicate some causal relationship.

According to our model, the early Neolithic sites in Eastern Europe belong to both waves in roughly equal numbers (56\% to near-eastern wave and $44 \%$ to eastern wave). Unlike elsewhere in Europe, the wave attributable to the Near East does not seem to have introduced farming in the East. The reason for this is not clear and may involve the local environment where low fertility of soils and prolonged winters are combined with the richness of aquatic and terrestrial wildlife resources (Dolukhanov 1996).

Regardless of the precise nature of the eastern source, the current work suggests the existence of a wave which spread into Europe from the east carrying the tradition of early Neolithic pottery-making. If confirmed by further evidence (in particular, archaeological, typological, and genetic), this suggestion will require serious re-evaluation of the origins of the Neolithic in Europe.

$$
\text { ACKNOWLEDGEMENTS }
$$

Financial support from the European Community's Sixth Framework Programme under the grant NEST028192-FEPRE is acknowledged.

\section{REFERENCES}

AMMERMAN A. J. \& BIAGI P. (eds.), 2003. The Widening Harvest. The Neolithic Transition in Europe: Looking Back, Looking Forward. Archaeological Institute of America. Boston.

AMMERMAN A. J. \& CAVALLI-SFORZA L. L. 1971. Measuring the rate of spread of early farming in Europe. Man 6 : $674-688$.

1973. A Population Model for the Diffusion of Early Farming in Europe. In C. Renfrew (ed.), The Explanation of Culture Change; Models in Prehistory. London, Duckworth.

1984. The Neolithic Transition and the Genetics of Populations in Europe. Princeton University Press. Princeton.

BERG P. L. V. \& HAUZER A. 2001. Le Néolithique ancien. Anthropologica et Praehistoria 112: 63-76.

BIRDSELL J. B. 1957. Some population problems involving Pleistocene man. Cold Spring Harbor Symposium on Quantitative Biology 22: 47-69.

BRONK RAMSEY C. 2001. Development of the Radiocarbon Program 0xCal. Radiocarbon 43: 355-363.
CAVALLI-SFORZA L. L. \& FELDMAN M. W. 1981. Cultural Transmission and Evolution: A Quantitative Approach. Princeton University Press. Princeton.

DAVISON K., DOLUKHANOV P. M., SARSON G. R. \& SHUKUROV A. 2006. The role of waterways in the spread of the Neolithic. Journal of Archaeological Science 33: 641-652.

DOLUKHANOV P. 1979. Ecology and Economy in Neolithic Eastern Europe. Duckworth. London.

DOLUKHANOV P., SHUKUROV A., GRONENBORN D., SOKOLOFF D., TIMOFEEV V. \& ZAITSEVA G. 2005. The Chronology of Neolithic Dispersal in Central and Eastern Europe. Journal of Archaeological Science 32: 1441-1458.

DOLUKHANOV P. M. 1996. The Early Slavs: Eastern Europe from the Initial Settlement to the Kievan Rus. Longman.

FORT J., PUJOL T. \& CAVALLI-SFORZA L. L. 2004. Palaeolithic populations and waves of advance. Cambridge Archaeological Journal 14: 53-61.

GKIASTA M., RUSSELL T., SHENNAN S. \& STEELE J. 2003. Neolithic transition in Europe: the radiocarbon record revisited. Antiquity 77: 45-61. 
GORDON CHILDE V. 1925. The Dawn of European civilization. Kegan Paul, Trench \& Trubner. London.

HAAK W., FORSTER P., BRAMANTI B., MATSUMURA S., BRANDT G., TÄNZER M., VILLEMS R., RENFREW C., GRONENBORN D., ALT K. W. \& BURGER J. 2005. Ancient DNA from the first European farmers in 7500-year-old Neolithic sites. Science 310: 1016-1018.

JEUNESSE C. 1987. Le céramique de la Hauguette. Un nouvel élément non rubané du Néolithique ancien de l'Europe de nord-ouest. Cahiers Alsasiens.

KUZMIN Y. V. \& ORLOVA L. 2000. The Neolithization of Siberia and the Russian Far East: Radiocarbon evidence. Antiquity 74: 356-364.

LUBBOCK J. 1865. Pre-historic Times: as Illustrated by Ancient Remains, and the Manners and Customs of Modern Savages. Williams and Norgate. London.

MAMONOV E. A. 2000. Khronologicheskii aspekt izucheniya yelshanskoi kul'tury. In E. N. Nosov (ed.), Khronologiya Neolita Vostochnoi Evropy. IIMK. St. Petersburg.

MURRAY J. D. 1993. Mathematical Biology. Springer-Verlag. Berlin.

OSHIBKINA S. V. 1996. Introduction. In S. V. Oshibkina (ed.), Neolit Severnoi Evrazii. Nauka. Moscow.

PERLÈS C. 2001. The Early Neolithic in Greece. The First Farming Communities in Europe. Cambridge University Press. Cambridge.

PINHASI R., FORT J. \& AMMERMAN A. J. 2005. Tracing the Origin and Spread of Agriculture in Europe. P.L.O.S. Bio$\log y$ 3: 2220-2228.

PRICE T. D. 2000. Europe's First Farmers. Cambridge University Press. Cambridge.
ROUSSAULT-LAROQUE J. 1990. Rubané et Cardial, le poids de l'ouest. Rubané et Cardial, ERAUL(Liège) 39: 315-360.

SHENNAN S. \& STEELE J. 2000. Spatial and Chronological Patterns in the Neolithisation of Europe. on-line: http://ads.ahds.ac.uk/catalogue/resources.html?c14_meso

STEELE J., ADAMS J. \& SLUCKIN T. 1998. Modelling Paleoindian Dispersals. World Archaeology 30: 286-305.

THISSEN L., REINGRUBER A. \& BISCHOFF D. 2006. CANeW, ${ }^{14} \mathrm{C}$ databases and chronocharts (2005-2006 updates). on-line: http://www.canew.org/data.html

THOMAS J. 1996. The cultural context of the first use of domesticates in Continental and Northwest Europe. In D. R. Harris (ed.), The Origins of Spread of Agriculture and Pastoralism in Eurasia. UCL Press, London.

TILLEY C. 1994. A Phenomenology of Landscape. Berg. Oxford.

TIMOFEEV V. I., ZAITSEVA G. I., DOLUKHANOV P. M. \& SHUKUROV A. M. 2004. Radiocarbon Chronology of the Neolithic in Northern Eurasia. Tesa. St. Petersburg.

WHITTLE A. 1996. Europe in the Neolithic. The Creation of New Worlds. Cambridge University Press. Cambridge.

YOUNG D. A. \& BETTINGER R. L. 1992. The Numic Spread: A Computer Simulation. American Antiquity 57: 85-99.

ZILHÃO J. 2001. Radiocarbon evidence for maritime pioneer colonization at the origins of farming in west Mediterranean. Proceedings of the National Academy of Sciences of the United States of America 98: 14180-14185.

ZVELEBIL M. 1996. The agricultural frontier and the transition to farming in the circum-Baltic region. In D. R. Harris (ed.), The Origins and Spread of Agriculture and Pastoralism in Eurasia. UCL Press, London. 